\title{
Antiviral Effect of Crude Aqueous Extracts from Ten Philippine Medicinal Plants against Zika Virus
}

\author{
Fatima Ericka S. Vista, ${ }^{1}$ Leslie Michelle M. Dalmacio, ${ }^{1}$ Laarni Grace M. Corales, ${ }^{1}$ \\ Gielenny M. Salem, ${ }^{2}$ Jedhan U. Galula² and Day-Yu Chao ${ }^{2}$ \\ ${ }^{1}$ College of Medicine, University of the Philippines Manila \\ ${ }^{2}$ Graduate Institute of Microbiology and Public Health, College of Veterinary Medicine, National Chung Hsing University, Taichung, Taiwan
}

\begin{abstract}
Objective. This study aimed to determine the antiviral activity of ten Philippine medicinal plants against Zika virus (ZIKV).

Methods. Lyophilized aqueous plant extracts were used for cell cytotoxicity and virus inhibition assays. The therapeutic index was computed from the $50 \%$ cytotoxic concentration (CC50) and $50 \%$ effective concentration (EC50) values. Plant metabolites were also identified using mass spectroscopy. An in-silico screening of these metabolites was done using ZIKV enzymes and the AxI protein in human microglial cells as target proteins, followed by the ranking of binding energy scores to generate a hypothesis on the possible mechanism of antiviral action.
\end{abstract}

Results. The plants that demonstrated the highest therapeutic index were Momordica charantia, Psidium guajava, Vitex negundo, and Blumea balsamifera. The majority of the metabolites present in the aqueous extracts were saponin, terpenes and terpenoids, and anthocyanin. Further, in-silico docking results showed a higher binding affinity for viral replication proteins compared to the viral envelope protein.

Conclusion. The crude aqueous extracts of M. charantia, P. guajava, V. negundo, and B. balsamifera were the most potent candidate antiviral therapies against ZIKV among the ten plants tested. Meanwhile, the in-silico results suggested that the metabolites possibly employ an intracellular mechanism for the observed antiviral activity.

Key Words: Zika virus, herbal medicine, virus inhibition, Momordica charantia, Psidium guajava

\section{INTRODUCTION}

Paper presented at the Philippine Society for Microbiology's $47^{\text {th }}$ Annual Convention and Scientific Meeting, July 19-20, 2018, The Oriental, Taysan Hill, Sto. Niño Village, Legazpi City, Albay; and at the Institute of Herbal Medicine's $2^{\text {nd }}$ Philippine Herbal Medicine Summit, October 4-5, 2018, AG New World Manila Bay Hotel, Pedro Gil St., Ermita, Manila.

Corresponding author: Fatima Ericka S. Vista College of Medicine, University of the Philippines Manila 547 Pedro Gil St., Ermita, Manila 1000, Philippines Email: fsvista2@up.edu.ph
Zika virus (ZIKV), a mosquito-borne flavivirus transmitted by Aedes spp., causes a disease with symptoms that include mild fever, skin rash, conjunctivitis, muscle and joint pain, malaise, and headache lasting for about two to seven days. ${ }^{1}$ The symptoms of ZIKV infection appear to be similar to those of other arbovirus infections such as dengue and infected people usually recover. However, in pregnant women, infection with Zika virus has been found to cause congenital brain abnormalities in their infants after exposure to the virus in utero. ${ }^{1}$

Currently, there are no specific treatments for ZIKV infection apart from bed rest and medications for pain and fever. There is also no vaccine available. ${ }^{1}$ Since viral infections are self-limiting leading either to immune clearance or host death, ${ }^{2}$ most are clinically handled through the management of symptoms. ${ }^{3}$ However, some herbal medicines have perceived antiviral effects based on folkloric claims. Previous studies have also shown that using the leaves of Psidium guajava results in an increase in platelet count after dengue 
infection, ${ }^{4}$ while the roots and fruits of Momordica charantia have shown inhibitory effects on dengue virus serotype 1 (DENV-1). ${ }^{4}$ Thus, these studies serve as a basis for further conducting studies on the antiviral effects of medicinal plants.

In the Philippines, the Department of Health (DOH) endorses ten herbal medicines ${ }^{5}$ that have clinically-proven medicinal value. They are as follows:

- Senna alata is also known as ringworm bush. As an herbal remedy, it is used against tinea infections, insect bites, ringworms, eczema, scabies and pruritus. ${ }^{5}$ Its leaves, flowers, stem, and root barks were previously shown to have broad-spectrum antimicrobial activity. ${ }^{6}$ Currently, no studies on its antiviral properties are reported.

- Momordica charantia or bitter gourd has compounds in its fruits and seeds that exhibit antidiabetic properties. ${ }^{7}$ It also shows anticancer activity with its fruits exhibiting inhibition of breast cancer growth ${ }^{7}$ while its leaves show anti-metastatic activity against prostate cancer. ${ }^{8} \mathrm{DOH}$ also endorses this plant for its folkloric use against hemorrhoids, coughs, burns, and scalds. ${ }^{5}$ Pongthanapisith et al. ${ }^{9}$ found that it has inhibitory activity against the $\mathrm{H} 1 \mathrm{~N} 1, \mathrm{H} 3 \mathrm{~N} 2$, and H5N1 subtypes of Influenza A. One of its proteins, MAP30, has inhibitory effects against HIV- $1^{10}$ while its roots and fruits were shown to inhibit dengue virus. ${ }^{4}$

- Allium sativum or garlic, which is claimed to reduce blood cholesterol levels is commonly used for hypertension. ${ }^{5}$ Nwokocha and colleagues demonstrated the hypotensive effect of aqueous garlic clove extracts on both normotensive and hypertensive rats. ${ }^{11}$ As an herbal remedy, it is also used as an antibacterial, antiinflammatory and anticancer treatment. ${ }^{5}$ As for its antiviral activities, studies have reported an in vitro activity against Influenza $\mathrm{A}$ and $\mathrm{B}$, cytomegalovirus, rhinovirus, HIV, herpes simplex virus 1 and 2, viral pneumonia, and rotavirus. ${ }^{12}$

- Psidium guajava, also known as guava is traditionally used as an antidiabetic medicine, ${ }^{5}$ and its leaves have been shown to lower blood glucose levels in vivo..$^{13}$ Its leaves also have inhibitory activities against $\mathrm{H} 1 \mathrm{~N} 1^{14}$ and simian rotavirus ${ }^{15}$. Other folkloric uses include use as an antiseptic, anti-inflammatory, antispasmodic, antioxidant, hepatoprotective, anti-allergy, antimicrobial, antiplasmodial, anti-cough and antigenotoxic treatment. ${ }^{5}$

- Vitex negundo also known as 5-leaved chaste tree is traditionally used to treat coughs, colds, and fever. ${ }^{5}$ It is also commonly used to treat a variety of diseases including diarrhea $\mathrm{a}^{5}$ since its leaves exhibit antimicrobial activity against bacteria such as Vibrio cholera and Escherichia coli. ${ }^{16}$ Other folkloric uses include use as a treatment for asthma, pharyngitis, rheumatism, dyspepsia, and boils. ${ }^{5}$ Meanwhile, Kothandan and Swaminathan ${ }^{17}$ evaluated its leaves' antiviral activity and found that while it could inhibit Asian strains of the chikungunya virus, it had a low selectivity index.
- Combretum indicum or Chinese honeysuckle is an herbal medicine whose leaves have anti-diarrheal properties. ${ }^{18}$ Traditionally, it is used against intestinal parasites. ${ }^{5}$ However, there are no reports on its antiviral activity.

- Blumea balsamifera or blue camphor is used in the Philippines as an herbal treatment for kidney stones. ${ }^{5}$ Montealegre et al. found that its leaves favor the formation of small crystals, beneficial to kidney stone formers. ${ }^{19}$ Folkloric uses include treatment for wounds, cuts, rheumatism, diarrhea, spasms, colds, coughs, and hypertension. ${ }^{5}$ Currently, no literature is available on its antiviral activities.

- Ehretia microphylla is also called wild tea. Chandrappa et al. found that its stem extract has anti-inflammatory activity in vitro. ${ }^{20}$ Traditionally, it is used as an herbal remedy for eczema, scabies, and pruritus. ${ }^{5}$ It is also used as an antispasmodic and anti-diarrheal treatment, disinfectant during childbirth, and mouthwash for tooth decay. ${ }^{21}$ However, its antiviral properties are not widely reported.

- Peperomia pellucida stem and leaf extracts are used to treat gout and arthritis. ${ }^{22}$ On the other hand, its antiviral activity has not yet been established.

- Clinopodium douglasii or peppermint leaves were found to have anti-asthmatic effect when combined with oregano. ${ }^{23}$ As an herbal remedy, it is used as a pain reliever as well as a treatment against rheumatism, gout, coughs, colds, and insect bites. ${ }^{5}$ However, its antiviral activities have not been reported.

Since little is known about the antiviral activities of most of these plants, this study aimed to determine their antiviral potential against the Zika virus. Further, ZIKV being an emerging threat to healthcare and a significant public health concern prompted the World Health Organization to advocate for the rapid development of treatment against ZIKV infections. ${ }^{24}$ Direct-acting antivirals were considered as a good option for treating ZIKV by repurposing already available drugs to address the ZIKV problem efficiently. ${ }^{24}$ In the Philippines, we have these ten medicinal plants that are already being used for their various health benefits and can serve as a good starting point in the search for cheaper, plant-based alternatives to synthetic, pharmaceutical drugs. ${ }^{25}$ This is important in the country since these plants are widely available and accessible especially in the provinces. Meanwhile, the in-silico part of this study aimed to find a possible mechanism for the metabolites in the crude aqueous extracts of the plants that exhibited antiviral activity.

\section{MATERIALS AND METHODS}

\section{Herbal Plant Crude Aqueous Extracts}

Fresh leaves of Vitex negundo, Psidium guajava, Ehretia microphylla, and Blumea balsamifera were collected from Tanauan, Batangas while those of Momordica charantia, 
Peperomia pellucida, and Clinopodium douglasii were collected from Sta. Rosa, Nueva Ecija. Senna alata leaves were collected from Morong, Bataan, while Combretum indicum leaves came from General Santos City, South Cotabato. Allium sativum cloves were collected from Ilocos Norte. Plant parts were washed with distilled water and air-dried before extraction. One hundred grams of cloves for $A$. sativum and dried leaves for all other plants were cut and soaked in $1 \mathrm{~L}$ of distilled water at $100^{\circ} \mathrm{C}$ for fifteen minutes. The resulting extracts were filtered through a muslin cloth to separate it from the plant parts before lyophilization. The lyophilized extracts were stored at $4^{\circ} \mathrm{C}$ until reconstitution. For the cytotoxicity test and virus inhibition assay, the extracts were reconstituted in Dulbecco's Modified Eagle Medium (DMEM), clarified by centrifugation, then filtered and stored at $-20^{\circ} \mathrm{C}$ until needed. For the screening of metabolites using mass spectroscopy, the extracts were reconstituted in HPLC-grade water before filtration.

\section{Cells and virus}

Vero cells were grown in Dulbecco's Modified Eagle's Medium (DMEM, Gibco Laboratories, Grand Island, NY, US), which was supplemented with $10 \%$ heat-inactivated fetal bovine serum (FBS, HyClone Laboratories Inc., Logan, UT, US), $2 \mathrm{mM}$ L-glutamine, $110 \mathrm{mg} / \mathrm{L}$ sodium pyruvate, 0.1 $\mathrm{mM}$ non-essential amino acids (Gibco, Life Technologies, Grand Island, NY), $20 \mathrm{mg} / \mathrm{L} 7.5 \% \mathrm{NaHCo}_{3}, 100 \mathrm{U} / \mathrm{mL}$ penicillin (Gibco Laboratories, Grand Island, NY, US) and $100 \mu \mathrm{g} / \mathrm{mL}$ streptomycin (Gibco Laboratories, Grand Island, NY, US). Cells were maintained at $37^{\circ} \mathrm{C}$ with $5 \% \mathrm{CO}_{2}$.

ZIKV strain MR766 was used for all virus inhibition assays, and was provided by Dr. Day-Yu Chao (NCHU, Taiwan). ZIKV stocks were propagated by infecting Vero cells in DMEM with 2\% FBS for 7 days, at a multiplicity of infection (MOI) of 1.0. Cell supernatants were harvested, clarified by centrifugation and stored in aliquots at $-80^{\circ} \mathrm{C}$ until use. Virus titers were determined by plaque assay on Vero cells (ATCC).

\section{Cytotoxicity test}

Cell cytotoxicitywas evaluatedusing 3-(4,5-dimethylthiazolyl-2)-2,5-diphenyltetrazolium bromide (MTT) assay following the protocol from American Type Culture Collection (2011) ${ }^{26}$ with some modifications. The cells were diluted to a density of $1.5 \times 10^{5}$ cells $/ \mathrm{mL}$ and $100 \mu \mathrm{L}$ was seeded onto a 96 -well plate. After 12 hours, $100 \mu \mathrm{L}$ of serially diluted extracts was added onto each well. Cells with medium (DMEM) only served as the positive control, while wells with media only served as the negative control. Each plant extract was serially diluted in triplicates. The plates were incubated for 4 days before the addition of $100 \mu \mathrm{L}$ of MTT reagent $(0.5 \mathrm{mg} / \mathrm{mL})$. The plates were then incubated in the dark at $37^{\circ} \mathrm{C}$ and $5 \% \mathrm{CO}_{2}$ for 4 hours followed by the addition of $100 \mu \mathrm{L}$ of DMSO. The plates were incubated again in the dark for 2 hours before reading the absorbance at $570 \mathrm{~nm}$.

\section{Virus Inhibition Assay}

To test for virus inhibition using plaque assay, the protocol of Baer \& Kehn Hall ${ }^{27}$ was followed with modifications. Vero cells at a density of $2.5 \times 10^{5}$ cells $/ \mathrm{mL}$ were seeded onto 12-well plates. Each of the plant extracts with a starting concentration between $0.0625 \mathrm{mg} / \mathrm{mL}$ and $1 \mathrm{mg} / \mathrm{mL}$ was serially diluted two-fold prior to incubation with ZIKV MR766 at $37^{\circ} \mathrm{C}$ with $5 \% \mathrm{CO}_{2}$ for 1 hour. Vero cells containing DMEM with $2 \% \mathrm{FBS}$ served as the negative control. After 1-hour incubation, $1 \%$ methylcellulose was used as an overlay medium, and plates were incubated at $37^{\circ} \mathrm{C}$ with $5 \% \mathrm{CO}_{2}$ for 4 days. Cells were fixed with $10 \%$ formaldehyde and stained with $0.5 \%$ crystal violet. Manual counting of the plaques was performed. All tests were done in duplicate.

\section{Determination of CC50, EC50, and Therapeutic Index}

The $\%$ cell viability of Vero cells after treatment with serially diluted plant extracts was calculated as:

\section{$\frac{\text { Abs (treated) - Abs (negative control) }}{\text { Abs (positive control) - Abs (negative control) }}$}

Logarithmic regression was used to determine the extract concentration at which only $50 \%$ of cells were viable. This concentration was considered the plant's CC50.

The potency of each plant extract concentration used was calculated as:

$$
\frac{\# \text { of plaques (treated) }}{\# \text { of plaques (control) }} \times 100
$$

Exponential regression was used to determine the extract concentration at which there was $50 \%$ potency. This concentration was considered the plant's EC50. The therapeutic index was calculated as the ratio of:

$$
\frac{\mathrm{CC} 50}{\mathrm{EC} 50}
$$

\section{Identification of Plant Metabolites via Mass Spectroscopy}

To identify the specific metabolites present in the crude aqueous extract of the top antiviral candidates, mass spectroscopy was performed. The lyophilized plant extracts were dissolved in liquid chromatography-mass spectrometry (LC-MS) grade water up to a final concentration of $0.5 \mathrm{mg} /$ $\mathrm{mL}$ and then filtered using a $0.2 \mu \mathrm{m}$ syringe filter. Separation was performed in a $2.1 \times 100 \mathrm{~mm} 1.8 \mu \mathrm{m} \mathrm{C} 18$ column at $40^{\circ} \mathrm{C}$. The mobile phase A contained $0.1 \%$ formic acid in water, while mobile phase B contained $0.1 \%$ formic acid in acetonitrile. Initial conditions were kept for one minute before using a linear gradient program of

$$
\frac{5 \% \text { phase } B}{95 \% \text { phase } A} \text { to } \frac{95 \% \text { phase } B}{5 \% \text { phase } A}
$$


for 10 minutes at a flow rate of $0.5 \mathrm{~mL} / \mathrm{min}$. For mass spectroscopy, the Waters UNIFI Scientific Information System v1.8.1.073 software was used. The parameters used were as follows: capillary voltage of $1.0 \mathrm{kV}\left(\mathrm{ESI}^{+}\right)$, source temperature at $120^{\circ} \mathrm{C}$, desolvation temperature at $550^{\circ} \mathrm{C}$, cone voltage of $40 \mathrm{~V}$, cone gas flow at $40 \mathrm{~L} / \mathrm{h}$, desolvation gas flow at $950 \mathrm{~L} / \mathrm{h}$, scan range from 50 to $1,200 \mathrm{~m} / \mathrm{z}$, scan time of 0.150 s, and a collision energy ramp from 15 to $50 \mathrm{eV}$ (high energy). Leucine enkephalin was used as a reference compound for mass correction.

\section{In silico Docking of Plant Metabolites}

Six candidate enzymes contributing to ZIKV cell entry and infection namely, ZIKV helicase (PDB ID: 5JRZ), ${ }^{28}$ protease (PDB ID: 5H4I), ${ }^{29}$ methyltransferase (PDB ID: $5 \mathrm{KQR}),{ }^{30}$ RNA-dependent RNA polymerase (PDB ID: 5U04), ${ }^{31}$ and envelope protein (PDB ID: $\left.5 \mathrm{JHM}\right)^{32}$ as well as the human Axl protein (PDB ID: 5U6B; Gajiwala \& Grodsky) ${ }^{33}$ were used for docking based on the work of Byler et al. $^{34}$ The structures were downloaded from the protein data bank (www.PDB.org). Their active sites were determined by observing the protein in Chimera where they were prepared for docking via the procedure outlined by Lang. ${ }^{35}$ AutoDock Tools v1.5.6 was used to create the docking grid box.

The metabolites identified using mass spectroscopy were searched against databases of Chem Spider and the Traditional Chinese Systems Pharmacology Database (TCMSP) for therapeutic potentials. Only ligands with available 3D structures were downloaded and prepared for docking using AutoDock Tools v1.5.6. A configuration file containing the docking grid dimensions was used for the actual docking experiment, which was performed in AutoDock Vina. Virtual screening was performed to generate the predicted free energy of binding for each metabolite. The metabolites were ranked according to their binding energies and tabulated for each plant.

\section{RESULTS}

\section{Determination of the CC50 and EC50 of the Ten Plants}

The MTT assay measures cell viability via the yellow MTT reagent that turns into purple-colored formazan when reduced by the dehydrogenase enzymes of metabolically active cells. ${ }^{26}$ Based on the CC50 data (Figure 1), the plant that was most cytotoxic to Vero cells was Ebretia microphylla $(0.2768 \mathrm{mg} / \mathrm{mL})$, while the least cytotoxic plant was Allium sativum $(9.91 \mathrm{mg} / \mathrm{mL})$.

Meanwhile, the plaque assay measures viral concentration by counting the number of discrete plaques visible on the plate. These plaques are indicative of cellular dead zones due to viral infection. ${ }^{27}$ This assay can be used to measure a treatment's potency by observing its plaque reduction capacity. Based on the EC50 values (Figure 2), the

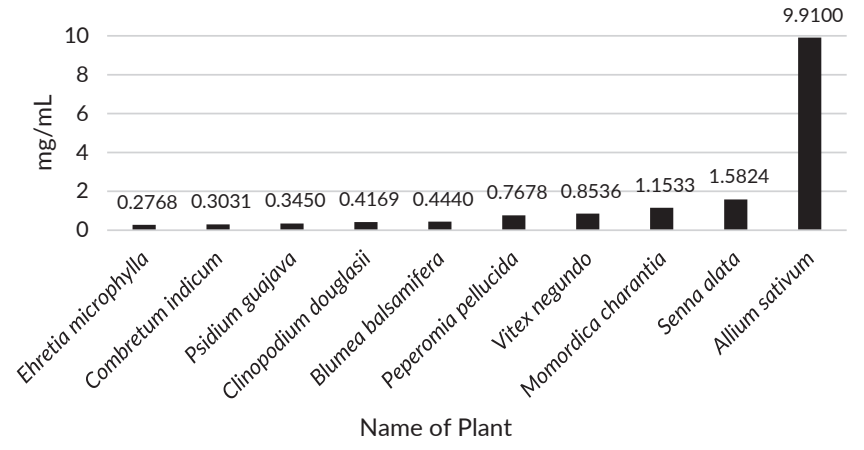

Figure 1. CC50 of the ten Philippine medicinal plants against ZIKV MR766.

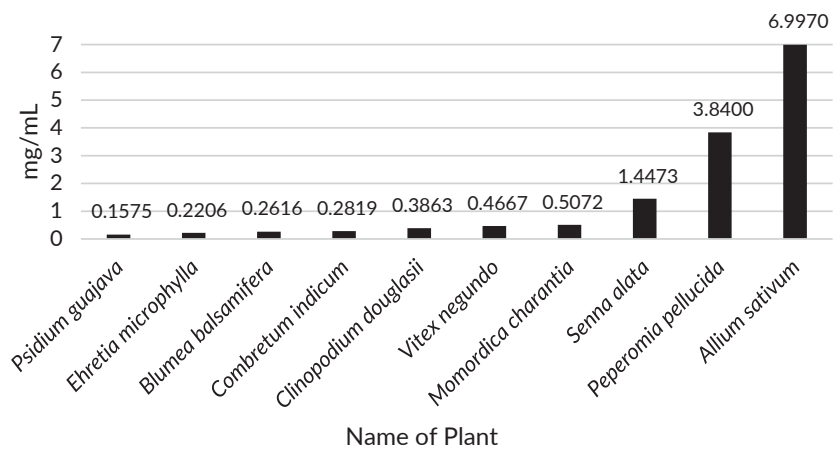

Figure 2. EC50 of the ten Philippine medicinal plants against ZIKV MR766.

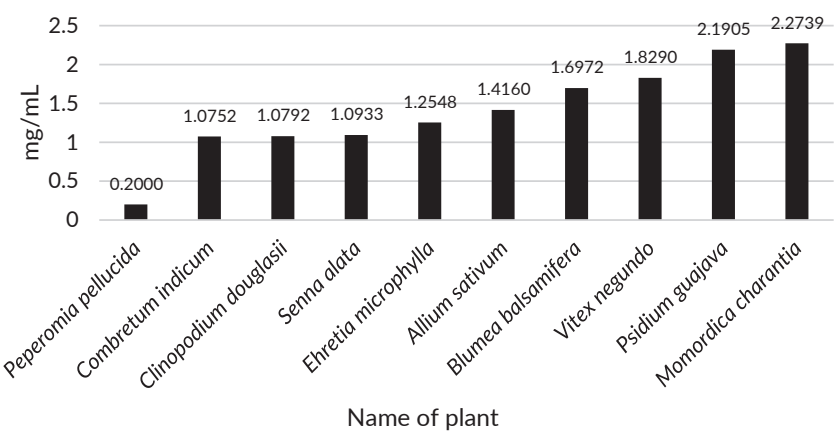

Figure 3. Therapuetic index of the ten Philippine medicinal plants against ZIKV MR766.

plant with the greatest antiviral effect was Psidium guajava $(0.1575 \mathrm{mg} / \mathrm{mL})$ while A. sativum $(6.997 \mathrm{mg} / \mathrm{mL})$ had the least antiviral effect.

\section{Determination of the Antiviral Candidates using Therapeutic Index}

Based on the ratio of the CC50 and EC50 values, the therapeutic indices were derived. A ranking of the plants' therapeutic indices (Figure 3) show that the four plants namely, Momordica charantia, Psidium guajava, Vitex negundo, and Blumea balsamifera, are antiviral candidates. 


\section{Identification of Metabolites from Crude Aqueous Extracts using Mass Spectroscopy}

This study found that saponins, terpenes, terpenoids, and anthocyanin were most commonly detected in the aqueous extracts. A comprehensive list and identity of the metabolites identified via mass spectroscopy are shown in Table 1 . The metabolites with the highest binding affinity for each of the top four plants include saikosaponin D in $M$. charantia, benzoyl paeniflorin in $P$ guajava, macrophylloside D in $V$. negundo, and cyanidin 3-5 diglucoside in B. balsamifera.

\section{In silico Docking of Metabolites to Proteins Involved in ZIKV Infection}

The plants that were determined to have good ZIKV inhibitory activity underwent metabolite identification and in silico docking to generate a hypothesis on a possible mechanism of action for the observed antiviral effects. Data on the metabolite binding energies are shown in Table 2. The binding energies generated are expressed in $\mathrm{kcal} / \mathrm{mol}$ and are measures of the strength of the interaction between the metabolite and the target protein. Binding energies of the top metabolites to the replication proteins ranged from -7 to $-9.5 \mathrm{kcal} / \mathrm{mol}$ compared to the range of -5.5 to -7.4 $\mathrm{kcal} / \mathrm{mol}$ for the viral envelope protein. Meanwhile, the binding affinity to the human Axl receptor ranged from -7.1 to $-9.3 \mathrm{kcal} / \mathrm{mol}$ for the top metabolites that bound to it.

\section{DISCUSSION}

\section{Determination of the CC50 and EC50 of the Ten Plants}

A high CC50 value is desired for potential drug leads since this means that it requires a high dosage before the treatment becomes cytotoxic. Meanwhile, a low EC50 value is ideal for potential drug leads because only a low concentration of the antiviral agent is needed to inhibit the virus. While the CC50 and EC50 values may suggest that E. microphylla is a poor antiviral candidate due to high cytotoxicity and that $P$. guajava has the best antiviral activity among the plants analyzed, this is not accurate. Therefore, the ratio between the two was used as an indicator of selectivity.

Table 1. Metabolites identified using mass spectroscopy

\begin{tabular}{|c|c|c|c|c|}
\hline Name of Plant & Metabolite & Observed mass (Da) & Observed $\mathrm{m} / \mathrm{z}$ & Observed RT (min) \\
\hline \multirow[t]{8}{*}{ M. charantia } & Saikosaponin D & 780.4676757 & 803.4568965 & 7.540168762 \\
\hline & Esculentoside B & 664.3831034 & 687.3723243 & 8.502177238 \\
\hline & Ganoderic acid $Y$ & 454.3443668 & 477.3335877 & 8.337738037 \\
\hline & Methyl euscaphate & 502.3668356 & 525.3560565 & 9.341717720 \\
\hline & Cimiside F & 650.4028926 & 673.3921134 & 5.725144863 \\
\hline & Esculentoside A & 826.4370781 & 849.4262989 & 7.599523067 \\
\hline & Pomolic acid & 472.3554303 & 495.3446511 & 10.12463284 \\
\hline & Ganoderic acid U & 472.3560403 & 495.3452611 & 10.91231728 \\
\hline P. guajava & Benzoylpaeniflorin & 600.1809998 & 601.1882762 & 6.502140999 \\
\hline \multirow[t]{11}{*}{ V. negundo } & Chrysanthemin & 448.1001575 & 449.1074339 & 3.429554224 \\
\hline & Cimcifugic acid B1 & 448.1002838 & 449.1075603 & 3.984580994 \\
\hline & Macrophylloside D & 558.1953234 & 581.1845442 & 3.015325069 \\
\hline & $5,7,2^{\prime}, 5^{\prime}$ - Tetrahydroxyflavone & 286.0477752 & 287.0550516 & 4.642369270 \\
\hline & Mudanpioside E & 526.1693374 & 549.1585582 & 3.860057831 \\
\hline & Cimiside $\mathrm{F}$ & 650.4028926 & 673.3921134 & 5.725144863 \\
\hline & Chrysanthemin & 448.1001575 & 449.1074339 & 3.429554224 \\
\hline & Tinoside & 520.1944627 & 543.1836835 & 5.497520447 \\
\hline & 8-epi Loganic acid & 376.1362061 & 399.1254270 & 1.985986829 \\
\hline & Dihydrobrusatol 1 & 522.2096901 & 545.1989110 & 3.901344061 \\
\hline & Andrographatoside & 498.2826021 & 521.2718229 & 6.256365299 \\
\hline \multirow[t]{10}{*}{ B. balsamifera } & Cyanidin 3,5-diglucoside & 610.1532610 & 633.1424819 & 3.752222300 \\
\hline & Retinol & 286.2291979 & 287.2364743 & 10.30376053 \\
\hline & Bruceine $\mathrm{F}$ & 428.1676404 & 451.1568612 & 6.139420033 \\
\hline & Delphinidin & 302.0421133 & 303.0493897 & 3.748351574 \\
\hline & Schizonepetoside A & 330.1674309 & 353.1566518 & 3.874173641 \\
\hline & Arnicolide D & 332.1594595 & 333.1667359 & 6.835141182 \\
\hline & 6,7-Dehydroartemisinic acid & 232.1458154 & 233.1530919 & 7.690526962 \\
\hline & Cylindrene & 232.1454386 & 233.1527151 & 6.930004120 \\
\hline & Kirenol & 338.2448700 & 361.2340909 & 8.367994308 \\
\hline & Nigakilactone $\mathrm{K}$ & 406.1962836 & 407.2035600 & 7.499149799 \\
\hline
\end{tabular}


Table 2. Top metabolite binding energies (in kcal/mol) for six key proteins in ZIKV infection for M. Charantia, P. Guajava, V. Negundo and B. Balsamifera

\begin{tabular}{|c|c|c|c|c|c|c|}
\hline Plant & $\begin{array}{l}\text { Methyltransferase } \\
\text { (replication protein) }\end{array}$ & $\begin{array}{l}\text { Helicase } \\
\text { (replication protein) }\end{array}$ & $\begin{array}{l}\text { Protease } \\
\text { (replication protein) }\end{array}$ & $\begin{array}{l}\text { Polymerase } \\
\text { (replication protein) }\end{array}$ & Envelope Protein & $A X L$ \\
\hline \multirow[t]{5}{*}{ M. charantia } & $\begin{array}{l}\text { Saikosaponin D } \\
-9.3\end{array}$ & $\begin{array}{l}\text { Saikosaponin D } \\
-9.5\end{array}$ & $\begin{array}{l}\text { Saikosaponin D } \\
-8.4\end{array}$ & $\begin{array}{l}\text { Saikosaponin D } \\
-9.1\end{array}$ & $\begin{array}{l}\text { Saikosaponin D } \\
-7.4\end{array}$ & $\begin{array}{l}\text { Saikosaponin D } \\
-9\end{array}$ \\
\hline & $\begin{array}{l}\text { Esculentoside B } \\
-8.9\end{array}$ & $\begin{array}{l}\text { Esculentoside A } \\
-8.6\end{array}$ & $\begin{array}{l}\text { Cimiside F } \\
-7.7\end{array}$ & $\begin{array}{l}\text { Cimiside F } \\
-9\end{array}$ & $\begin{array}{l}\text { Cimiside F } \\
-7.2\end{array}$ & $\begin{array}{l}\text { Pomolic acid } \\
-8\end{array}$ \\
\hline & $\begin{array}{l}\text { Ganoderic acid } Y \\
-8.6\end{array}$ & $\begin{array}{l}\text { Cimiside F } \\
-8.5\end{array}$ & $\begin{array}{l}\text { Methyl euscaphate } \\
-7.7\end{array}$ & $\begin{array}{l}\text { Esculentoside A } \\
-8.4\end{array}$ & $\begin{array}{l}\text { Pomolic acid } \\
-6.6\end{array}$ & $\begin{array}{l}\text { Ganoderic acid U } \\
-8\end{array}$ \\
\hline & $\begin{array}{l}\text { Methyl euscaphate } \\
-8.3\end{array}$ & $\begin{array}{l}\text { Esculentoside B } \\
-8.4\end{array}$ & $\begin{array}{l}\text { Ganoderic acid } Y \\
-7.6\end{array}$ & $\begin{array}{l}\text { Ganoderic acid } Y \\
-8\end{array}$ & $\begin{array}{l}\text { Esculentoside A } \\
-6.1\end{array}$ & $\begin{array}{l}\text { Cimiside F } \\
-8\end{array}$ \\
\hline & $\begin{array}{l}\text { Cimiside F } \\
-8.1\end{array}$ & $\begin{array}{l}\text { Pomolic acid } \\
-8.1\end{array}$ & $\begin{array}{l}\text { Pomolic acid } \\
-7.3\end{array}$ & $\begin{array}{l}\text { Methyl euscaphate } \\
-7.9\end{array}$ & $\begin{array}{l}\text { Esculentoside B } \\
-6.1\end{array}$ & $\begin{array}{l}\text { Ganoderic acid } Y \\
-8\end{array}$ \\
\hline P. guajava & $\begin{array}{l}\text { Benzoyloxy- } \\
\text { paeniflorin } \\
-9.8\end{array}$ & $\begin{array}{l}\text { Benzoyloxy- } \\
\text { paeniflorin } \\
-8.2 \\
\end{array}$ & $\begin{array}{l}\text { Benzoyloxy- } \\
\text { paeniflorin } \\
-8.3\end{array}$ & $\begin{array}{l}\text { Benzoyloxy- } \\
\text { paeniflorin } \\
-8.8 \\
\end{array}$ & $\begin{array}{l}\text { Benzoyloxy- } \\
\text { paeniflorin } \\
-6.6 \\
\end{array}$ & $\begin{array}{l}\text { Benzoyloxy- } \\
\text { paeniflorin } \\
-9.3 \\
\end{array}$ \\
\hline \multirow[t]{5}{*}{ V. negundo } & $\begin{array}{l}\text { Chrysanthemin } \\
-9\end{array}$ & $\begin{array}{l}\text { Macrophylloside D } \\
-9.1\end{array}$ & $\begin{array}{l}\text { Macrophylloside D } \\
-8.7\end{array}$ & $\begin{array}{l}\text { Cimiside F } \\
-9\end{array}$ & $\begin{array}{l}\text { Cimiside } \mathrm{F} \\
-7.2\end{array}$ & $\begin{array}{l}\text { Cimiside } \mathrm{F} \\
-8.4\end{array}$ \\
\hline & $\begin{array}{l}\text { Cimicifugic acid B1 } \\
-9\end{array}$ & $\begin{array}{l}\text { Cimiside F } \\
-8.5\end{array}$ & $\begin{array}{l}\text { Mudanpioside E } \\
-8\end{array}$ & $\begin{array}{l}\text { Macrophylloside D } \\
-8.1\end{array}$ & $\begin{array}{l}\text { Tinoside } \\
-5.9\end{array}$ & $\begin{array}{l}\text { Macrophylloside D } \\
-8.3\end{array}$ \\
\hline & $\begin{array}{l}\text { Macrophylloside D } \\
-8.8\end{array}$ & $\begin{array}{l}\text { Chrysanthemin } \\
-8.3\end{array}$ & $\begin{array}{l}\text { Cimiside } \mathrm{F} \\
-7.7\end{array}$ & $\begin{array}{l}\text { Dihydrobrusatol1 } \\
-8\end{array}$ & $\begin{array}{l}\text { 5,7,2',5'-Tetra- } \\
\text { hydroxy-flavone } \\
-5.8 \\
\end{array}$ & $\begin{array}{l}\text { Tinoside } \\
-7.9\end{array}$ \\
\hline & $\begin{array}{l}\text { 5,7,2',5'-Tetra- } \\
\text { hydroxy-flavone } \\
-8.1\end{array}$ & $\begin{array}{l}\text { Mudanpioside E } \\
-8.1\end{array}$ & $\begin{array}{l}\text { Chrysanthemin } \\
-7.7\end{array}$ & $\begin{array}{l}\text { Tinoside } \\
-7.9\end{array}$ & $\begin{array}{l}\text { Andrographatoside } \\
-5.8\end{array}$ & $\begin{array}{l}\text { Mudanpioside E } \\
-7.9\end{array}$ \\
\hline & $\begin{array}{l}\text { Mudanpioside E } \\
-8.2\end{array}$ & $\begin{array}{l}\text { Tinoside } \\
-8 \\
\end{array}$ & $\begin{array}{l}\text { 8-epi-Loganic acid } \\
-7.7\end{array}$ & $\begin{array}{l}\text { Andrographatoside } \\
-7.5\end{array}$ & $\begin{array}{l}\text { Cimicifugic acid B1 } \\
-5.8\end{array}$ & $\begin{array}{l}\text { Chrysanthemin } \\
-7.8\end{array}$ \\
\hline \multirow[t]{5}{*}{ B. balsamifera } & $\begin{array}{l}\text { Cyanidin } \\
3,5 \text {-diglucoside } \\
-8.6 \\
\end{array}$ & $\begin{array}{l}\text { Cyanidin } \\
\text { 3,5-diglucoside } \\
-9.2\end{array}$ & $\begin{array}{l}\text { Cyanidin } \\
3,5 \text {-diglucoside } \\
-8.1\end{array}$ & $\begin{array}{l}\text { Cyanidin } \\
3,5 \text {-diglucoside } \\
-7.5\end{array}$ & $\begin{array}{l}\text { Cyanidin } \\
3,5 \text {-diglucoside } \\
-6.4\end{array}$ & $\begin{array}{l}\text { Cyanidin } \\
\text { 3,5-diglucoside } \\
-8\end{array}$ \\
\hline & $\begin{array}{l}\text { Retinol } \\
-7.9\end{array}$ & $\begin{array}{l}\text { Bruceine F } \\
-8.6\end{array}$ & $\begin{array}{l}\text { Arnicolide D } \\
-7.9\end{array}$ & $\begin{array}{l}\text { Delphinidin } \\
-7.3\end{array}$ & $\begin{array}{l}\text { Bruceine F } \\
-5.6\end{array}$ & $\begin{array}{l}\text { Delphinidin } \\
-7.6\end{array}$ \\
\hline & $\begin{array}{l}\text { Bruceine F } \\
-7.8\end{array}$ & $\begin{array}{l}\text { Delphinidin } \\
-7.7 \\
\end{array}$ & $\begin{array}{l}\text { Delphinidin } \\
-7.5 \\
\end{array}$ & $\begin{array}{l}\text { Bruceine F } \\
-7.3\end{array}$ & $\begin{array}{l}\text { Delphinidin } \\
-5.6\end{array}$ & $\begin{array}{l}\text { Arnicolide D } \\
-7.2\end{array}$ \\
\hline & $\begin{array}{l}\text { Delphinidin } \\
-7.8\end{array}$ & $\begin{array}{l}\text { Schizonepetoside A } \\
-7.5\end{array}$ & $\begin{array}{l}\text { 6,7-Dehydro- } \\
\text { artemisinic acid } \\
-7.1\end{array}$ & $\begin{array}{l}\text { Schizonepetoside A } \\
-7.2\end{array}$ & $\begin{array}{l}\text { Arnicolide D } \\
-5.5\end{array}$ & $\begin{array}{l}\text { Bruceine F } \\
-7.1\end{array}$ \\
\hline & $\begin{array}{l}\text { Schizonepetoside A } \\
-7.8\end{array}$ & $\begin{array}{l}\text { Retinol } \\
-7.1\end{array}$ & $\begin{array}{l}\text { Cylindrene } \\
-7.1\end{array}$ & $\begin{array}{l}\text { Nigakilactone K } \\
-7\end{array}$ & $\begin{array}{l}\text { Kirenol } \\
-5.5\end{array}$ & $\begin{array}{l}\text { Kirenol } \\
-7.1\end{array}$ \\
\hline
\end{tabular}

\section{Determination of the Antiviral Candidates using Therapeutic Index}

The therapeutic index is a more reliable measure of the plant's antiviral potential compared to CC50 or EC50 alone. A high therapeutic index is indicative of a plant's potential as a good candidate against the virus since this means that it has a relatively high CC50 value compared to its EC50 value. Momordica charantia, Psidium guajava, and Vitex negundo, three of the four antiviral candidates found in this study, already have established antiviral activities based on the literature. $M$. charantia is known to have antiviral activity against Influenza $\mathrm{A}^{9}, \mathrm{HIV}-1^{10}$ and dengue ${ }^{4}$, while $P$. guajava has been shown to inhibit $\mathrm{H} 1 \mathrm{~N} 1^{14}$ and simian rotavirus. ${ }^{15}$ Vitex negundo, on the other hand, has antiviral activity against chikungunya virus but was also shown to have a low selectivity index. ${ }^{17}$ The results of the present study support the claim that these three plants are potential antiviral agents and may therefore serve as rich sources of metabolites with high antiviral activities. This study also identified a new antiviral candidate, B. balsamifera. Meanwhile, Allium satioum had the poorest antiviral activity among the ten plants based on EC50 despite having an established antiviral activity against other viruses like Influenza $A$ and $B$, cytomegalovirus, rhinovirus, $\mathrm{HIV}$, herpes simplex virus 1 and 2, viral pneumonia, and rotavirus. ${ }^{12}$ Despite having a therapeutic index of 1.416, which was fifth out of the ten plants, it qualifies as a poor antiviral candidate against ZIKV because it requires a very high dose before exhibiting antiviral activity. Meanwhile, the plants that ranked sixth to ninth namely, Ehretia microphylla, Senna alata, Clinopodium douglasii and Combretum indicum, 
had therapeutic indices close to 1.0. Although they may have antiviral potential, they may not be good candidates since their effective concentration (EC50) against ZIKV is also close to its cytotoxic concentration. Peperomia pellucida showed the lowest therapeutic index (0.2). A value of less than 1.0 means that its cytotoxic properties exceed its antiviral properties hence a poor antiviral candidate.

\section{Identification of Metabolites from Crude Aqueous Extracts using Mass Spectroscopy}

According to Cowan, ${ }^{36}$ the analysis of plants and their components usually begins by exploring plants already used by local healers. For extractions, crude aqueous or alcohol extracts are commonly used for the first screening, and then other organic extraction methods follow ${ }^{36}$ should the plant show promising potential. The goal in extraction procedures is to separate the soluble active components of the plant using selective solvents. ${ }^{37}$ Since solvents have varying polarities, the use of a particular solvent would result in a distinct metabolite profile. It was found that in aqueous extracts, active components present include anthocyanins, tannins, saponins, and terpenoids as well as starches, polypeptides, and lectins. ${ }^{36}$ This is consistent with the results found in this study.

As for the metabolites with the highest binding affinity for each plant, three out of the four already have known antiviral activities. Saikosaponin D found in M. charantia in this study was isolated from Bupleurum falcatum L. by Ushio \& Abe, ${ }^{38}$ and was found to have direct inactivating effects on both the measles virus and herpes simplex virus. Benzoyl paeoniflorin found in P. guajava is also present in Paeonia delavayi root extracts and has been proven to have antiviral activity against influenza virus. ${ }^{39}$ The observed antiviral activity was even higher than that of oseltamivir, an anti-flu drug currently in the market. ${ }^{39}$ Meanwhile, cyanidin 3-5, diglucoside from B. balsamifera is one of the main anthocyanins found in elders, and these plants are known to have compounds with antiviral activity. ${ }^{40}$ It is also highly antioxidant, and is known to be a potent anticancer agent. ${ }^{40}$ These metabolites are good candidates for further studies since the literature has established that they possess antiviral activities while the results of this study show that they are present in plants with antiviral activity and they exhibit high binding affinity to viral proteins in silico.

\section{In silico Docking of Metabolites to Proteins Involved in ZIKV Infection}

The binding energy is a measure of the change in Gibb's free energy, ${ }^{41}$ so more negative values are desired since this is also reflective of a metabolites' higher binding affinity to the protein. The binding affinities of the plant metabolites to the viral replication proteins were generally higher compared to that of the viral envelope protein which suggests that the mechanism of viral inhibition is more likely to be via binding with intracellular viral replication proteins than via extracellular binding to the ZIKV envelope protein.
Further, the results showed that the metabolites may have antiviral potential via binding with viral replication proteins. Meertens et al. identified the Axl as the protein that binds ZIKV in human microglia, thus mediating infection. ${ }^{42}$ The high binding affinity to the Axl protein suggests that if tested on human glial cells, it is possible that the plant metabolites from $M$. charantia, $P$ guajava, $V$. negundo, and $B$. balsamifera can inhibit ZIKV by binding to the Axl protein and thus preventing host cell attachment.

\section{CONCLUSION}

The results of the study show that $M$. charantia, P. guajava, $V$. negundo, and B. balsamifera are the best candidates against ZIKV among the ten plants. Although E. microphylla has high antiviral activity, it is not a good candidate because of its high cytotoxic property. Similarly, A. sativum would also not make a good candidate despite being the least cytotoxic because it also has the weakest antiviral activity. Lastly, the in-silico findings of the study suggest that intracellular binding with viral replication proteins may be a likely mechanism for the plant metabolites in ZIKV inhibition. It is recommended to further study the antiZIKV effects of the top four plants as well as the mechanism behind the viral inhibition by the plant metabolites that exhibited the highest binding affinities in silico. Since only crude extracts were used in this study, it is recommended to explore the isolation of specific metabolites in future experiments. Additionally, the metabolites identified in this study are limited to those present in the aqueous extracts of the plants. For further studies, the use of other solvents is recommended since this may uncover other metabolites with potential antiviral activity.

\section{Statement of Authorship}

All authors participated in data collection and analysis, and approved the final version submitted.

\section{Author Disclosure}

All authors declared no conflicts of interest.

\section{Funding Source}

This paper was funded by the Department of Science and Technology - Philippine Council for Health Research and Development (DOST-PCHRD).

\section{REFERENCES}

1. Zika virus [Internet]. World Health Organization. World Health Organization [cited 2016 Oct 24]. Available from: http://www. who.int/mediacentre/factsheets/zika/en/.

2. Kane M, Golovkina T. Common threads in persistent viral infections. J Virol. 2010; 84(9):4116-23.

3. Symptoms, Testing, \& Treatment $\mid$ Zika virus | CDC [Internet]. Centers for Disease Control and Prevention. Centers for Disease Control and Prevention [cited 2019 Mar31]. Available from: http://www.cdc.gov/zika/symptoms/index.html. 
4. Abd Kadir SL, Yaakob H, Mohamed Zulkifli R. Potential antidengue medicinal plants: a review. J Nat Med. 2013; 67(4):677-89.

5. Health Guide [Internet]. Department of Health [cited 2016 Oct 24]. Available from https://riitmc.doh.gov.ph/index.php/en/health-guide.

6. Khan M, Kihara M, Omoloso AD. Antimicrobial activity of Cassia alata. Fitoterapia. 2001; 72(5):561-4.

7. Ray RB, Raychoudhuri A, Steele R, Nerurkar P. Bitter melon (Momordica charantia) extract inhibits breast cancer cell proliferation by modulating cell cycle regulatory genes and promotes apoptosis. Cancer Res. 2010; 70(5):1925-31. doi: 10.1158/0008-5472.CAN09-3438.

8. Pitchakarn P, Ogawa K, Suzuki S, Takahashi S, Asamoto M, Chewonarin T, Momordica charantia leaf extract suppresses rat prostate cancer progression in vitro and in vivo. Cancer Sci. 2010; 101(10):2234-40. doi: 10.1111/j.1349-7006.2010.01669.x.

9. Pongthanapisith V, Ikuta K, Puthavathana P, Leelamanit, W. Antiviral protein of Momordica charantia L. inhibits different subtypes of Influenza A. Evid Based Complement Alternat Med. 2013; 2013:729081.

10. Lee-Huang S, Huang PL, Chen HC, Huang PL, Bourinbaiar A, Huang HI, et al. Anti-HIV and anti-tumor activities of recombinant MAP30 from bitter melon. Gene. 1995; 161(2):151-6.

11. Nwokocha CR, Ozolua RI, Uwu DU, Nwokocha MI, Ugwu AC. Antihypertensive properties of Allium sativum (garlic) on normotensive and two kidney one clip hypertensive rats. Niger J Physiol Sci. 2011; 26(2):213-8.

12. Harris JC, Cottrell SL, Plummer S, Lloyd, D. Antimicrobial properties of Allium sativum (garlic). Appl Microbiol Biotechnol. 2001; 57(3):282-6.

13. OhWK, Lee CH,Lee MS, Bae EY, Sohn CB, Oh H, et al. Antidiabetic effects of extracts from Psidium guajava. J Ethnopharmacol. 2005; 96(3):411-5.

14. Sriwilaijaroen N, Fukumoto S, Kumagai K, , Hiramatsu H, Odagiri T, Tashiro M, et al. Antiviral effects of Psidium guajava Linn. (guava) tea on the growth of clinical isolated H1N1 viruses: Its role in viral hemagglutination and neuraminidase inhibition. Antiviral Res. 2012; 94(2):139-46.

15. Gonçalves JL, Lopes RC, Oliveira DB, Costa SS, Miranda MM, Romanos MT, et al. In vitro anti-rotavirus activity of some medicinal plants used in Brazil against diarrhea. J Ethnopharmacol. 2005;99(3):403-7.

16. Kamruzzaman M, Bari SM, Faruque SM. In vitro and in vivo bactericidal activity of Vitexnegundo leaf extract against diverse multidrug resistant enteric bacterial pathogens. Asian Pac J Trop Med. 2013; 6(5):352-9.

17. Kothandan S, Swaminathan R. Evaluation of in vitro antiviral activity of Vitex negundo L., Hyptis suaveolens (L) poit., Decalepishamiltonii Wight \& Arn., to Chikungunya virus. Asian Pac J Trop Dis. 2014;4(Suppl 1): S111-S115.

18. Singh N, Mohan G, Sharma RK, Gnaneshwari D. Evaluation of anti-diarrhoeal activity of Quisqualis indica L. leaves. Indian J Nat Prod Resour. 2013; 4(2):155-60.

19. Montealegre CM, Ilao AC, Mendoza RVT, Carpio RPM, de Leon RL. Effect of Blumea balsamifera extract in the kinetics of calcium oxalate crystallisation. Chem Eng Trans. 2017; 56:1633-1638.

20. Chandrappa CP, Govindappa M, Anil Kumar NV, Channabasava R. In vitro Anti-Inflammatory Activity of Carmona retusa (VAHL.). World J Pharm Pharm Sci. 2013; 2(5):3991-7.

21. Tsaang Gubat or Wild Tea (Ehretia microphylla Lam.) [Internet]. Tsaang Gubat / Wild Tea (Ehretia microphylla Lam.) [cited 2019 Mar31]. Available from: http://www.philippineherbalmedicine.org/ tsaang_gubat.htm.
22. Majumder P. Phytochemical, pharmacognostical and physicochemical standardization Pepperomia pellucida (L.) HBK. stem. International Journal of Comprehensive Pharmacy. 2011; 2(8):1-4.

23. Boy HIA, Rutilla AJH, Santos KA, Ty AMT, Yu AI, Mahboob T, et al. Recommended Medicinal Plants as Source of Natural Products: A Review. Digitial Chinese Medicine. 2018; 1(2):131-42.

24. Mittal R, Nguyen D, Debs LH, Patel AP, Liu G, Jhaveri VM, et al. Zika virus: an emerging global health threat. Front Cell Infect Microbiol. 2017; 7:486.

25. Ammakiw CL, Odiem MP. Availability, preparation and uses of herbal plants in Kalinga, Philippines. Eur Sci J. 2013; 4:483-489.

26. MTT Cell Proliferation Assay [Internet]. American Type Culture Collection; [cited 2017 June 9]. Available from: https://www.atcc. org/ /media/DA5285A1F52C414E864C966FD78C9A79.ashx

27. Baer A, Kehn-Hall K. Viral concentration determination through plaque assays: using traditional and novel overlay systems. J Vis Exp. 2014; (93):e52065. doi: 10.3791/52065.

28. Jain R, Coloma J, García-Sastre A, Aggarwal AK. Structure of the NS3 helicase from Zika virus. Nat Struct Mol Biol. 2016; 23(8):752-4.

29. Zhang Z, Li Y, Loh YR, Phoo WW, Hung AW, Kang C, et al. Crystal structure of unlinked NS2B-NS3 protease from Zika virus. Science. 2016; 354(6319):1597-600.

30. Coloma J, Jain R, Rajashankar KR, Garcia-Sastre A, Aggarwal AK. Structures of NS5 Methyltransferase from Zika Virus. Cell Rep. 2016;16(12):3097-3102.

31. Godoy AS, Lima GM, Oliveira KI, Torres NU, Maluf FV, Guido $\mathrm{RV}$, et al. Crystal structure of Zika virus NS5 RNA-dependent RNA polymerase. Nat Commun. 2017; 8:14764.

32. Dai L, Song J, Lu X, Deng YQ, Musyoki AM, Cheng H, et al. Structures of the Zika Virus envelope protein and its complex with a flavivirus broadly protective antibody. Cell Host Microbe. 2016; 19(5):696-704.

33. Gajiwala KS, Grodsky N, Bolaños B, Feng J, Ferre R, Timofeevski S, et al. The Axl kinase domain in complex with a macrocyclic inhibitor offers first structural insights into an active TAM receptor kinase. J Biol Chem. 2017; 292(38):15705-16.

34. Byler KG, Ogungbe IV, Setzer WN. In-silico screening for anti-Zika virus phytochemicals. J Mol Graph Model. 2016; 69:78-91.

35. Lang PT. Preparing Molecules for DOCKing [Internet]. University of California San Francisco [cited 2017 Sept 18]. Available from: http://dock.compbio.ucsf.edu/DOCK_6/tutorials/struct_prep/ prepping_molecules.htm.

36. Cowan MM. Plant products as antimicrobial agents. Clin Microbiol Rev.1999; 12(4):564-82.

37. Azwanida NN. A review on the extraction methods use in medicinal plants, principle, strength and limitation. Med Aromat Plants. 2015; 4:196.

38. Ushio Y, Abe H. Inactivation of Measles Virus and Herpes Simplex Virus by Saikosaponin d. Planta Med. 1992; 58(2):171-3.

39. Li J, Yang X, Huang L. Anti-influenza virus activity and constituents. Characterization of Paeonia delavayi extracts. Molecules. 2016; 21(9):1133.

40. Buhner SH. Herbal Antivirals: Natural Remedies for Emerging \& Resistant Viral Infections. Storey Publishing; 2013.

41. Copeland RA. Evaluation of enzyme inhibitors in drug discovery a guide for medicinal chemists and pharmacologists. Hoboken, NJ: Wiley; 2013.

42. Meertens L, Labeau A, Dejarnac O, Cipriani S, Sinigaglia L, BonnetMadin L, et al. Axl mediates ZIKA virus entry in human glial cells and modulates innate immune responses. Cell Rep. 2017;18(2):324-33. 